\title{
生態学的パラメータによる河川 底生動物群集の動態特性の評価
}

\author{
渡辺幸三 1 ・吉村千洋 ${ }^{2}$ - 小川原享志 ${ }^{3} \cdot$ 大村達夫 $^{4}$ \\ ${ }^{1}$ 工修 日本学術振興会特別研究員 東北大学博士後期課程学生 大学院工学研究科土木工学専攻 \\ （于 980-8579 仙台市青葉区荒巻字青葉 06） \\ ${ }^{2}$ 正会員 工博 日本学術振興会特別研究員 東北大学 同上 \\ 3 東北大学博士前期課程学生 同上 \\ ${ }^{4}$ 正会員 工博 東北大学教授 同上
}

\begin{abstract}
河川底生動物群集の評価は, 群集の定常性を前提とした研究が多いが, 群集の動態(時間変化)も考虑した 研究は少ない.そこで本研究では, 密度依存性と確率変動成分を考慮した数理モデルである群集動態モデル を東京都に分布する底生動物群集(N=70)のバイオマスの経年変化に適用した. そして,そのモデルパラメー 夕( $\mathrm{K}$ : 環境収容力, $\mathrm{r}$ : 比增加速度, s: 変動強度)を推定して動態特性を定量的に把握し, その特性と河川環 境や種多様性等との関連性を調べた，その結果, 生息環境の溶存酸素濃度(DO)が低い群集ほど K の值が低 く, sの值が高くなり，浮遊物質(SS)が高いほど $\mathrm{K}$ の值が低い傾向がわかった．また，下流に進み河川の規 模(流量, 低水敷幅)が大きくなるほど Kの值は小さくなり, 一方 $\mathrm{s}$ の值が大きくなる傾向も明らかになった.
\end{abstract}

Key Words: river ecosystem, benthic faunal community, community dynamics model, Gompertz model, stochastic fluctuation, parameter estimation

\section{1.はじめに}

近年，河川生態系に対する国民の関心はきわめて 高く，河川管理における生態系に配慮した環境保全 のあり方が問われている1), 2).この観点から, 河川水 辺の国勢調査3)をじめ, 河川に生息する生物のモ二 タリングが活発に行われてきた ${ }^{4)}$.5).これらのモニタ リングは水生生物の生息状況を評価して, 河川空間 において自然生態系を保全・復元することを目的と して行われており, 魚類, 底生動物, 藻類などを対象 生物とすることが多い.これらの中で, 底生動物はサ ンプリングの容易さ, 魚類に比べて狭い河川環境 (瀬一淵構造)を反映するなどの特性から,より多くの 調查や研究の対象とされてきた ${ }^{6)-8)}$.

底生動物群集の生息状態(バイオマス, 総個体群密 度, 種数, 種多様性等)は季節変化や生態遷移などの 時間変化が起きている9)-12). 従来, 生息状態を評価す る際には，その時間平均などで代表させて評価する ことが多かったが, 平均值で評価する場合, 群集動態 が見せる傾向や変動強度などの底生動物群集に関す る重要な情報が無視される恐れがある.したがって, 底生動物群集の生息状態をより忠実に評価するため
には, 定常性とともに非定常性も前提とした, 生態遷 移や回復現象などの群集動態の評価も必要とされる.

この群集動態は時間オーダーにより季節変化と経 年変化に大別される(更に細かく見れば経時変化もあ る). 季節変化の評価では, 種ごとに異なる孵化や羽 化などの生活環による群集の内部構造の変化に主に 着目することになる. 一方, 経年変化の評価では, 群 集の内部構造よりも, むしろ生活環とは関連が低い 群集の生息状態の変化(生態遷移や回復など)が重要と なる.この経年変化に関する研究は, 調查に長期間を 要するためか, 季節変化に比べて圧倒的に事例が少 ないのが現状である. しかし, 今後, 底生動物の群集 動態を評価していく上で, 経年変化の特性も把握し ていくことが必要となる.

これまで, 生物群集の動態を把握する有効な手段 として, 群集の時間変化を表現する数理モデルであ る群集動態モデルが様々な生物を対象に開発されて (る ${ }^{13)-16)}$ 。これら動態モデルに含まれる複数のパラ メータによって群集の動態特性が表現される. した がって, フィールドで得られた時系列データに群集 動態モデルを適用し,パラメータ推定を行うことによ り,これまで困難だった動態特性の評価が可能とな 
る.にも関わらず, 河川底生動物群集の時間的な変化 を定量的に解析した研究は少なく,また, 底生動物の 経年変化に群集動態モデルを適用した研究事例はほ とんど無い.

以上より, 本研究は数理モデルである群集動態モ デルを河川底生動物群集のバイオマス(総現存量)の経 年変化に適用することでモデルパラメータを推定し, それにより動態特性を明らかにすることを目的とし た. さらに, パラメータにより示される動態特性と河 川環境(水質,川幅,流量等)や生息状態(バイオマス, 総 個体群密度, 種数, 種多様性)との関連性を調べた. 群 集動態の特性は種数や種多様性など他の側面からも 評価されるべきであるが，本研究ではモデルへの適 用が比較的容易なバイオマスの動態に主眼を置いた. バイオマスは河川生態系の中で底生動物にストック されたエネルギー量を表す17).よって, バイオマスの 動態には底生動物群集の生産量と呼吸量のバランス の時間変化が反映されるので, 河川生態系のエネル ギ一動態を評価するのに最適な変数と言える. なお, 本研究では,バイオマスを「単位面積に生息する全底 生動物種の湿重量の合計」として用いた。

\section{2. 方法}

\section{（1）群集動態モデル}

\section{a) モデルの選択}

御勢9は吉野川(奈良県)に生息する底生動物群集の バイオマスについて，伊勢湾台風からの経年的な回 復過程を調べた. そして, バイオマスの経年変化は時 間経過に伴って増加速度が低下し，最終的に平衡バ イオマスに達するジグモイド(S字)型の曲線をたどる 密度依存性を示すことを明らかにした. また, この他 にも，様々な生息地の䚓乱によって減少した底生動 物群集のバイオマスが経年的に回復することが報告 されている11),12)。一方, 底生動物群集の動態には密 度依存性の他にも河川の特徵である非生物環境(流量 や水質等)の変動や生物間相互作用 $\left.{ }^{18)}, 19\right)$ による生物環 境の変動も影響する ${ }^{20)}$, 21)。しかし，これらの環境変 動による影響を決定論的に説明するには膨大な数の パラメータが必要となり，モデルを実際の動態評価 に用いる際に碩健性を失う.また, 環境変動への影響 因子自体もまだまだ未解明な点が多いので, 密度依 存性以外の影響である環境変動はノイズに集約して 扱い, 1 つ確率過程で考えるのが妥当である.また, 個体数やバイオマスが非常に小さい群集(e.x., 絶滅に 瀕している集団)では，モデルの確率過程として環境 変動の他に人口学的確率性を考慮する場合がある ${ }^{16)}$.
しかし, 本研究で扱う底生動物群集のバイオマスは そのサイズが十分に大きいため，この影響は無視し てモデルを考えた。

以上より, 底生動物のバイオマスの経年変化を表 す群集動態モデルとして, Goel ら 22)が提案した式(1) を選択した。このモデルは決定論的に「密度依存性」 を表現する左辺および右辺第 1 項の Gompertz モデル と「環境変動」を過去の傾向から統計的に表現する右 辺第 2 項の確率変動成分 $(\mathrm{s} F(\mathrm{t}) \mathrm{x})$ から構成される.な お，密度依存性を表現する決定論的モデルには logistic モデル ${ }^{23)}$ な゙゙いくつかあるが，確率変動成分 を組み込んだ際に, 解析解が存在する Gompertz モデ ルをベースとした式(1)を本研究では選択した.

$$
\frac{d x}{d t}=-r x \ln \left(\frac{x}{K}\right)+s F(t) x
$$

$$
\begin{array}{ll}
\mathrm{x}: \text { バイオマス }\left[\mathrm{mg} / \mathrm{m}^{2}\right] & \mathrm{K}: \text { 環境収容力 }\left[\mathrm{mg} / \mathrm{m}^{2}\right] \\
\mathrm{t}: \text { 時間 [year] } & \mathrm{r}: \text { 比増加速度 }[/ \mathrm{year}] \\
\mathrm{s}: \text { 変動強度 }[-] & \mathrm{F}(\mathrm{t}): \text { ホワイトノイズ }[/ \text { year }]
\end{array}
$$

図-1は式(1)の群集動態確率モデルおよびそのベー スとなる Gompertz モデルが記述するバイオマスの経 年変化の概念図である. Gompertz モデルにおいて, r はバイオマス $\mathrm{x}$ が $\mathrm{K} / \mathrm{e}$ の場合の比増加速度を表す(eは 自然対数の底)。式(1)で表されるバイオマスは, Gompertz モデルの挙動を中心に変動強度 s の振動を 伴いながら環境収容力 $\mathrm{K}$ へ近づき, 最終的に $\mathrm{K}$ の周 りを振動し続ける定常状態に達する.

Goel らは確率モデルの解析解の導出に有効な Fokker-Planck 方程式を活用して, 式(1)の解析解を

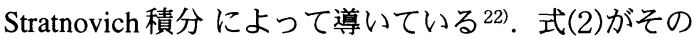
解であり, バイオマス $\mathrm{x}$ を変数とする確率密度関数と して与えられる. $\mathrm{P}(\mathrm{x} \mid \mathrm{y}, \mathrm{t}, \mathrm{K}, \mathrm{r}, \mathrm{s})$ は初期バイオマス $\mathrm{y}$ が $\mathrm{t}$ 年後に $\mathrm{x}$ に変化する確率である.

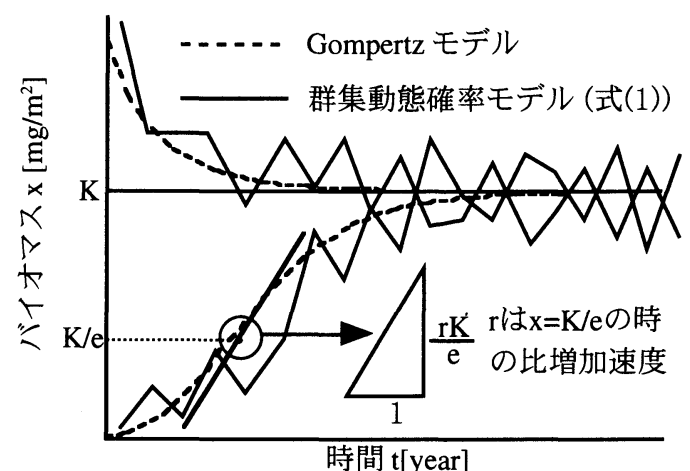

図 -1＼cjkstart群集動態確率モデルの概念図 
$P(x \mid y, t, K, r, s)=\frac{1}{x} \sqrt{\frac{r}{\pi s^{2}\left(1-e^{-2 r t}\right)}} \exp \left[-\frac{r\{U(x)\}^{2}}{s^{2}\left(1-e^{-2 r t}\right)}\right]$

ただし $\quad \mathrm{U}(\mathrm{x})=\ln \frac{\mathrm{x}}{\mathrm{K}}\left(\frac{\mathrm{K}}{\mathrm{y}}\right)^{\exp (-\mathrm{rt})}$

\section{b) 群集動態の特性を表すパラメータ}

群集動態確率モデル(式(1))では, 環境収容力 K, 変 動強度 $\mathrm{s}$, 比増加速度 $\mathrm{r}$ の 3 つのパラメータによって 動態特性が規定される．経年的にサンプリングされ た底生動物のバイオマスにモデルを適用することで これらのパラメータは推定される。

表-1にパラメータ(K, s, r)の性質についてまとめた. 1つ目のパラメータの環境収容力 $\mathrm{K}$ は，その生息環境 が維持できるバイオマスの大きさを表す．河川底生 動物の場合, 水質, 河床状態, および気候などの非生 物環境亡魚類(捕食者)や藻類(被食者)などの生物環境 がバイオマスの大きさを規定する.これらの環境状 態は毎年変化するが，環境収容力 $\mathrm{K}$ はその平均的な 状態を表す. 2 つ目の変動強度 $\mathrm{s}$ は, Gompertz モデル では表現されない非生物環境の変化や生物間相互作 用による生物環境の変化の大きさを表す. Goel らが 式(1)を開発した際, 変動強度 $\mathrm{s}$ は生物間相互作用(補 食・被食関係)による個体群動態の変動を表すパラ メータとして考えた ${ }^{22)}$. しかし, 本研究ではモデルを 適用する場である河川の特徵を考慮し, 変動強度 $\mathrm{s}$ 非生物環境の変動(流量変動等)も含めて表すパラメー 夕として拡張して考えた. 3つ目の比増加速度 $\mathrm{r}$ は, 単 位バイオマス当たりの年間の生産量の高さを表す. また, この值が高い群集ほど, 洪水や土木工事などに よるバイオマスの一時的低下からの回復が速いこと を意味する．底生動物は種ごとの出生率や死亡率に よって増殖速度が異なるので ${ }^{24)}$, 群集の種構成が影 響すると考えられる.

また，底生動物群集の動態を表すパラメータ $(\mathrm{K}, \mathrm{s}$, r)は, 川の流れに沿って個体が流下する移入・移出に よっても影響を受けると考えられる．各個体の生活
型, 河床状態, 流速などがこの移入・移出に影響して いる ${ }^{26)}$. 例えば, 移出よりも移入が強い生息地では, 比増加速度 $\mathrm{r}$ や環境収容力 $\mathrm{K}$ が高くなることが推測さ れる.これは, 移入によりバイオマスの比増加速度や その河川環境に存在する量が高められるからである. また, 移入・移出が各年で大きく異なる群集は, 変動 強度 $\mathrm{s}$ がより大きくなることも考えられる．そこで, 本研究では, これらの移入・移出の影響も含めた群集 動態の特性を表す指標としてパラメータ $(\mathrm{K}, \mathrm{s}, \mathrm{r})$ を考 えた.

\section{（2）パラメータの推定}

河川環境に生息する群集の動態を理解するために, 野外で得られたバイオマスの時系列データからパラ メー夕 $(\mathrm{K}, \mathrm{s}, \mathrm{r})$ を推定する方法を開発した。この方法 では, 変動強度(s)の大きさはバイオマスの変動の大 きさから推定する. また, 比増加速度 $\mathrm{r}$ の推定值には 急激にバイオマスが増加している群集の比増加速度 の実測値を用いる場合もあるが16), 本研究では, その ような増加過程に限らず, 飽和過程や減少過程, ある いはこれらが複合的に絡んだ過程のバイオマスの時 系列デー夕からも $\mathrm{r}$ を推定できる方法を開発した.

パラメータ推定は式(2)を用いた最尤推定法 ${ }^{25}$ によ り行った.なお, 他の確率モデルに関するパラメータ 推定を行った Hakoyama and Iwasa ${ }^{15)}$ の手法を参考に し, 新たに尤度関数を作った.ここで, $\mathrm{n}$ 年分のバイ オマスの実測値を 1 年目から順に $\mathrm{x}_{1}, \cdots, \mathrm{x}_{\mathrm{i}}, \mathrm{x}_{\mathrm{i}+1}, \cdots$ , $\mathrm{x}_{\mathrm{n}}$ と表記すると, $\mathrm{x}_{\mathrm{i}}$ から $\tau$ 年後に $\mathrm{x}_{\mathrm{i}+\tau}$ に変化する確率 は, 式(2)より $\mathrm{P}\left(\mathrm{x}_{\mathrm{i}+\tau} \mid \mathrm{x}_{\mathrm{i}}, \tau, \mathrm{K}, \mathrm{r}, \mathrm{s}\right)$ と表される.この確率

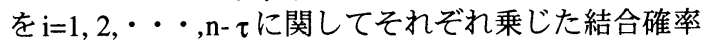
密度関数を尤度関数として最尤推定を行った. そし て, 以下に示すパラメータとバイオマスの関係式(式 (3)-(5))を導いた[付録 1 参照].

$$
e^{-\tau \tau}=\frac{\sum_{i=1}^{n-\tau} \ln x_{i} \sum_{i=1}^{n-\tau} \ln x_{i+\tau}-(n-\tau) \sum_{i=1}^{n-\tau} \ln x_{i+\tau} \ln x_{i}}{\left(\sum_{i=1}^{n-\tau} \ln x_{i}\right)^{2}-(n-\tau) \sum_{i=1}^{n-\tau}\left(\ln x_{i}\right)^{2}}
$$

表-1 群集動態モデルのパラメータ $(\mathrm{K}, \mathrm{s}, \mathrm{r})$ の性質. 河川底生動物の場合, ここでの影響以外に移入・移出がパラメータ の推定值に影響する.

\begin{tabular}{|c|c|c|}
\hline パラメータ & 意味 & $\begin{array}{c}\text { パラメータへの影響が推測される要因 } \\
\text { (河川底生動物群集の場合) }\end{array}$ \\
\hline $\begin{array}{l}\text { 環㙋 } \\
{[\mathrm{m}}\end{array}$ & $\begin{array}{l}\text { 物供給 } \\
\text { ス }\end{array}$ & $\begin{array}{l}\text {-水質, 河床, 気候などの非生物環境 } \\
\text { ·魚類(捕食者)や澡類(被食者)の生息状況 }\end{array}$ \\
\hline $\mathrm{s}:$ 変動強度 & $\begin{array}{l}\text { ・環境変動や生物間相互作用で生じるバイ } \\
\text { オマスの変動の大きさ }\end{array}$ & $\begin{array}{l}\text { ・流量や気候などの非生物環境の変動 } \\
\text { ·魚類(捕食者)や藻類(被食者)との相互関係 }\end{array}$ \\
\hline $\begin{array}{l}\mathrm{r}: \text { 比増加速度 } \\
{[/ \mathrm{year}]}\end{array}$ & $\begin{array}{l}\text { ・值が高い程一時的な減少からバイオマス } \\
\text { が速く回復する }\end{array}$ & $\begin{array}{l}\text { ・群集の種構成(種ごとに違う出生率や死亡 } \\
\text { 率が反映される) }\end{array}$ \\
\hline
\end{tabular}




$$
\begin{gathered}
\ln K=\frac{1}{(n-\tau)\left(1-e^{-r \tau}\right)} \sum_{i=1}^{n-\tau}\left[\ln \left\{\frac{x_{i+\tau}}{x_{i}{ }^{\operatorname{xxp}(-r \tau)}}\right\}\right] \\
\frac{s^{2}(n-\tau)\left(1-e^{-2 r \tau}\right)}{2 r}=\sum_{i=1}^{n-\tau}\left[\ln \left\{\frac{x_{i+\tau}}{K}\left(\frac{K}{x_{i}}\right)^{\exp (-r \tau)}\right\}\right]^{2}
\end{gathered}
$$

パラメータは $\tau=1$ の場合に関する推定から行う．ま ず，式(3)を用いて $\mathrm{r}$ を求める. そして，求めた $\mathrm{r}$ を式 (4)に代入して K を求め, 最後に式(5)にこれらの $\mathrm{r}$ と $\mathrm{K}$ の値を代入して $\mathrm{s}$ を求める.

比増加速度 $\mathrm{r}$ の範囲は $\mathrm{r}>0$ なので, $0<\mathrm{e}^{-\mathrm{r}}<1$ である. よって, 式(3)の右辺が 1 以上, 0 以下となる群集は, $\tau=1$ の場合, $\mathrm{r}$ の解が存在しないのでパラメータ $(\mathrm{K}, \mathrm{s}$, r)を推定できない.この場合, 推定値を求めるために,


マスに関して,その確率過程の 2 年後への変化に着目 して最尤推定が行われる. ただし, $\tau=2$ とすると尤度 関数に用いる確率密度関数の数 $(\mathrm{n}-\tau)$ が $\tau=1$ の場合よ りも1つ少なくなるため, その分, 推定の信頼性が低 下することに注意する必要がある，そして，仮に， $\tau=1$ に引き続き $\tau=2$ の場合でも推定できなかった場 合には $\tau=3$, それでも無理ならば $\tau=4$ というように 推定できるまで $\tau$ を随時大きくしていった.

\section{（3）対象とした底生動物群集}

\section{a）東京都に分布する底生動物群集}

本研究では, 東京都が行った生物調査の結果 ${ }^{26)}$ に モデルを適用した。この生物調查は図-2に示した環 境基準点(42 地点)で 1986 年度 1997 年度(12 年間) に渡って実施された，底生動物の採集は，水深が深 く, 石喽が少ない地点ではエクソン・バージ型採泥機
（合計採集面積 $0.24 \mathrm{~m}^{2}$ )，水深が浅く石礫があるよう な場所ではコドラード付きサーバネット(同 $0.27 \mathrm{~m}^{2}$ ) でそれぞれ行われた。調查地点は内陸部から海に近 い感潮域まで東京都全域に渡る．海水が流入する感 潮域では淡水域とは大きく異なる生態系が構築され る32)。しかし, バイオマスの経年データがあれば, 淡 水域と同様に感潮域の群集も群集動態モデルに適用 してパラメータを推定できる. 黒丸で表示された 14 地点では 5 月， 8 月， 11 月， 2 月期の毎年 4 回調査さ れ, 白丸で表示された 28 地点は毎年 8 月期の 1 回の み行われている.これらを合わせると延べ 84 群集が 調査されたことになる。これらのバイオマスを採集 面積が $1.0\left[\mathrm{~m}^{2}\right]$ となるようにそれぞれ換算し，式(5), (6), (7)を使ってパラメー夕(K, s, r) を推定した.なお, ここでのパラメータ推定值には生物調査が行われた 12 年間に群集が示していた動態特性が表現されるこ とになる. したがって，この 12 年間以外の期間，あ るいはこの 12 年間の一部の期間の経年データからパ ラメータを推定した場合, ここでの推定值と等しく なるとは限らないので注意する必要がある.

本研究はバイオマスの季節変化ではなく, 経年変 化を対象としている. また, 同地点であっても季節ご とに群集構成が大きく異なることから，5，8，11，2 月期における経年的な動態を解析するため, 各季節 に生息する群集のパラメー夕をそれぞれ推定した

\section{b) モデルの適用限界}

以下の 2 つ適用限界条件に当てはまるバイオマ スの経年データにはモデルを適用しなかった.

(1)デー夕時系列に $0\left[\mathrm{mg} / \mathrm{m}^{2}\right]$ となる年が含まれる場合 (2)デー夕期間に, バイオマスを一時的に変化させる

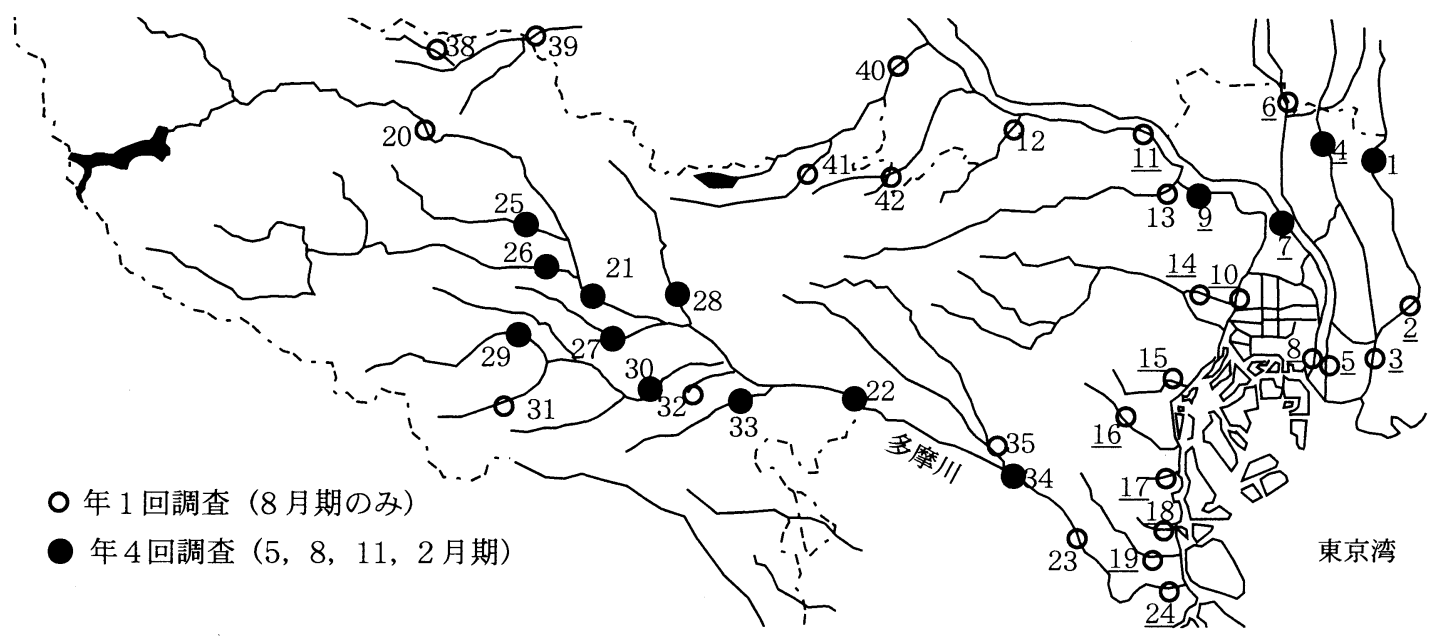

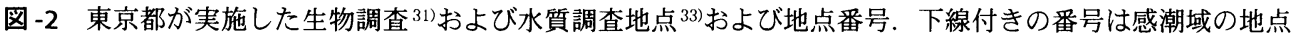
(電気伝導度の年平均が $5000 \mu \mathrm{S} / \mathrm{cm}$ を越えた地点を感潮域とした東京都の定義 ${ }^{31)}$ に基づく). 
人為的インパクト(河川改修工事など)があった場合

前者(1) はある年の生物調査で底生動物が採取でき ずにバイオマスが $0\left[\mathrm{mg} / \mathrm{m}^{2}\right]$ となった場合，その翌年 以降に底生動物が採取されることを式(1)が表現でき

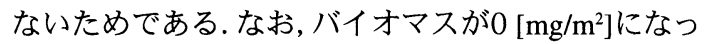
たのは, 環境中に底生動物が全く存在しなかったか らではなく, 生息密度が非常に低かったためサンプ ル面積に個体が入らなかったからと考えられる。し たがって, 今後, モデルに適用できるサンプリング データを得るためには, 生息密度が低い地点では採 集面積を広めに設定することが望まれる.ところで, 適用限界(1)適合した 10 群集は, モデルを適用する ために, $0\left[\mathrm{mg} / \mathrm{m}^{2}\right]$ のデータについて, それに近い状 態を表す 12 年間の算術平均を $10^{-1}$ 倍や $10^{-2}$ 倍した値 などを代用する方法も考えられた。しかし，この場 合, 算術平均を何倍した值を代用するかによって推 定值に大きく影響するため, この操作は行わなかっ た[付録 2 参照].

一方, 後者(2))の状況では底生動物群集が通常の動 態特性を示さないためモデルを適用しなかった。例 えば，土木工事によるバイオマスの一時的な低下 ${ }^{19)}$ は通常の生態系の営みでは見られない動態として考 えられる. 本研究では, 通常の群集動態を把握するこ とを目指しているので, 後者に当てはまるデー夕は 適用しなかった. ただし, 例えば慢性的な水質污濁な どは通常の状態と考えられる.よって, 単に人為的イ ンパクトの有無ではなく, その人為的インパクトが 一時的であるかを基準にモデルを適用する群集を選 択した.

以上より, 延べ総地点数と等しい84群集のうち, 適 用限界条件(1)と(2))に当てはまらない 70 群集(淡水 域: 53 群集, 感潮域: 17 群集)の時系列デー夕を群集 動態モデルに適用し,パラメータ $(\mathrm{K}, \mathrm{s}, \mathrm{r})$ を推定した.

\section{（4）パラメータと生息環境の相関分析}

底生動物群集の生物量, 群集構成, そして構成種な どは生息環境(水質, 流量, 河川形状等)により規定さ れる27-29).この群集と生息環境の密接な関係から, 群 集の動態特性にも各生息環境が反映していることが 予測される.そこで, この検証を行うため, 動態特性 を表すパラメータ $(\mathrm{K}, \mathrm{s}, \mathrm{r})$ と生息環境を表す基本的な 12 項目の環境変数との相関を調べた. 相関は群集ご とに推定されたパラメータと環境変数を用いた $\mathrm{F}$ 検 定(無相関の帰無仮説の棄却検定)により調べた.ま た, 比較対象として, 従来から底生動物群集の評価に 頻繁に用いられているバイオマスの平均値(パラメー 夕推定に使ったバイオマスデータの時間平均) との相
関も $\mathrm{F}$ 検定で調べた.

検定に用いた環境変数は水質項目と物理項目に分 かれる. 水質項目は東京都 ${ }^{30}$ が生物調査と同地点で 毎月測定したDO, COD, BOD, SS, 電気伝導度, $\mathrm{pH}$, 全 リン, 全窒素の8 項目である. 検定には, パラメータ 推定に関係した年の全ての月の水質データの算術平 均を用いた. また, 物理項目は標高, 集水面積（その 地点より上流側の集水面積), 低水路幅(常時水が流れ る川幅), 流量の 4 項目である . 流量は水質項目と同 様に全月の平均値を検定に用いた。

\section{（5）パラメータと生物指標の相関分析}

底生動物群集の生息状況の評価では, 総個体群密 度, バイオマス, 多様性指数, 分類数(種数)が指標之 して用いられることが多い.ここでは,これら既存の 4指標と群集動態を表すパラメータ $(\mathrm{K}, \mathrm{s}, \mathrm{r})$ との相関を 調べるために, F検定を行った，検定には，各群集の パラメー夕推定値と4指標の值を用いた. 指標の値は パラメー夕推定に使った各年の生物データからそれ ぞれ計算し, その時間平均を使った. なお, 全群集に 関して各指標の年変動はそれほど大きくはなかった (変動係数は概ね 2 以下). 分類数と多様性指数の計算 に用いた分類群は基本的に種レベルとしたが，種ま で同定されていない場合は属, 科, 目のレベルの順に 同定されていた分類群を使用した．多様性指数には Simpson index ${ }^{31)}$ を用いた。

\section{3. 結果および考察}

\section{（1） 底生動物群集の動態特性を示すパラメータ a) パラメータ推定值の頻度分布}

前述した最尤推定法により, 全70群集のうち 38 群 集が $\tau=1,16$ 群集が $\tau=2,6$ 群集が $\tau=3,7$ 群集が $\tau=4$, 2 群集が $\tau=5,1$ 群集が $\tau=6$ に関してパラメータが推 定された. 東京都の 70 群集において推定された各パ ラメータの範囲は, 環境収容力 K で 54-79479[mg/ $\left.\mathrm{m}^{2}\right]$, 変動強度 $\mathrm{s}$ で0.13-5.85[-], 比増加速度 $\mathrm{r}$ の0.026.40[/year] となった. 図-3に推定されたパラメータ $(\mathrm{K}, \mathrm{s}, \mathrm{r})$ の頻度分布を示す. ただし, 環境収容力 $\mathrm{K} の$ 頻度分布(図-3(a))はKを常用対数 $\left(\log _{10} \mathrm{~K}\right)$ に変換して 示してある. また，表-2には，それぞれの頻度分布 に関する統計量を示した.

環境収容力の対数の頻度分布 (図-3(a)) は右側に歪

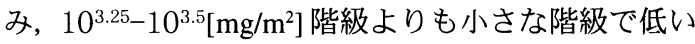
頻度が続いていた。分布の代表値は，算術平均が $10^{3.73}(=5383)\left[\mathrm{mg} / \mathrm{m}^{2}\right]$, 最頻值が $10^{3.88}(=7498)[\mathrm{mg} /$ $\left.\mathrm{m}^{2}\right]$, 中央值が $10^{3.93}(=8546)\left[\mathrm{mg} / \mathrm{m}^{2}\right]$ であった. なお, 
(a) $\mathrm{K}$ ：環境収容力 $\left[\mathrm{mg} / \mathrm{m}^{2}\right]$

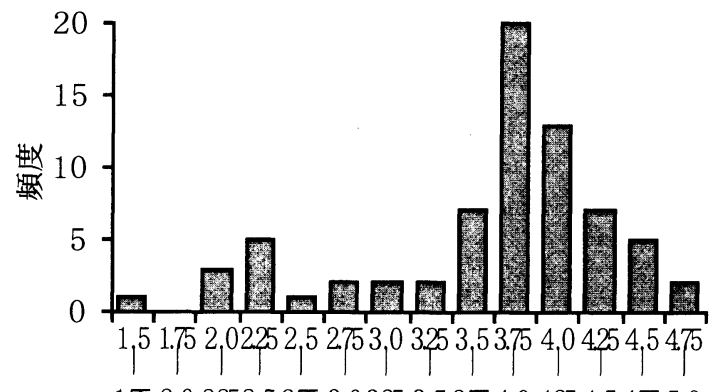

1.752 .02252 .52753 .03253 .53 .754 .04254 .54755 .0

環境収容力(対数) $\log _{10} \mathrm{~K}$

(b) $\mathrm{s}$ : 変動強度 $[-]$

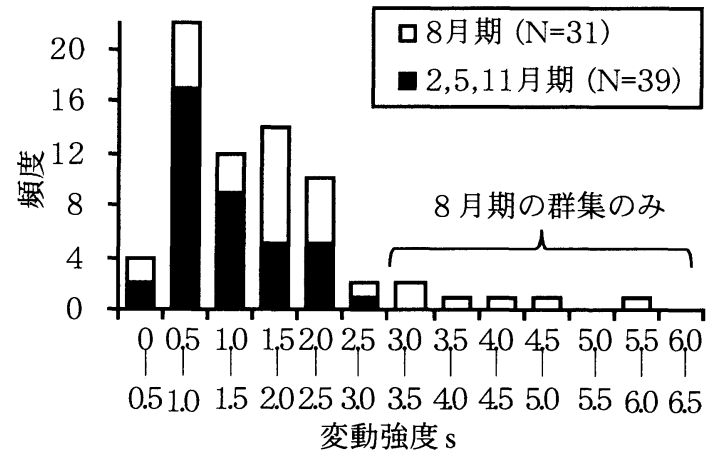

(c) $\mathrm{r}$ : 比增加速度 [/year $]$

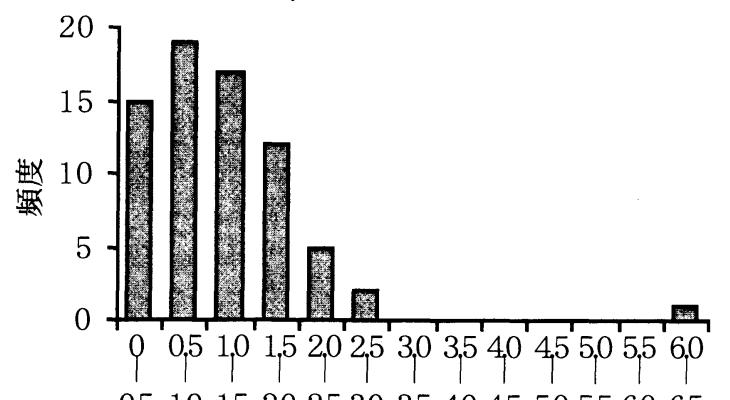

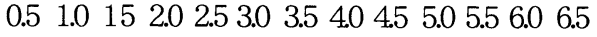
比増加速度 $\mathrm{r}$

図-3 最尤推定法により推定された各群集のパラメータ $(\mathrm{K}, \mathrm{s}, \mathrm{r})$ の頻度分布 $(\mathrm{N}=70)$.

表-2 パラメータ推定値に関する統計量 $(\mathrm{N}=70)$.

\begin{tabular}{c|c|c|c}
\hline & $\begin{array}{c}\text { 環境収容力 } \\
\log _{10} \mathrm{~K}\end{array}$ & $\begin{array}{c}\text { 変動強度 } \\
\mathrm{s}\end{array}$ & $\begin{array}{c}\text { 比増加速度 } \\
\mathrm{r}\end{array}$ \\
\hline 算術平均 & 3.73 & 1.59 & 1.17 \\
最頻値 & 3.88 & 0.75 & 0.75 \\
中央値 & 3.93 & 1.39 & 1.07 \\
標準偏差 & 0.74 & 1.04 & 0.92 \\
変動係数 & 0.20 & 0.65 & 0.79 \\
最小值 & 1.74 & 0.13 & 0.02 \\
最大值 & 4.90 & 5.85 & 6.40 \\
尖度 & 0.42 & 4.14 & 13.76 \\
歪度 & -1.03 & 1.74 & 2.78 \\
\hline
\end{tabular}

一般的に, バイオマスが $20000\left[\mathrm{mg} / \mathrm{m}^{2}\right]$ を越えるとバ イオマスがかなり高い群集に分類される ${ }^{32)}$. 環境収 容力 K の最大値はSt.21 (5 月期)における $10^{4.9}$ (=79479) $\left[\mathrm{mg} / \mathrm{m}^{2}\right]$ であった. St.21 は多摩川の中流域 に位置し, 護岸は自然状態に近い33).また, 群集は主 にカゲロウやトビケラから成り, 少数種による著し い優占はない ${ }^{31}$. なお，この地点では 5 月期以外の 3 季節でも環境収容力 $\mathrm{K}$ が高かった。ところで, $10^{5.0}\left[\mathrm{mg} / \mathrm{m}^{2}\right]$ よりも高い階級の頻度はすべて0であっ た.よって, 東京都内において, 底生動物群集のバイ オマスの維持に適した環境であっても, 維持できる バイオマスには約 $100\left[\mathrm{~g} / \mathrm{m}^{2}\right]\left(=10^{5.0}\left[\mathrm{mg} / \mathrm{m}^{2}\right]\right)$ 程度の上 限があると考えられる. 津田 ${ }^{32}$ は, 底生動物群集のバ イオマスは, 特別に高い場合でも 80 から $120\left[\mathrm{~g} / \mathrm{m}^{2}\right]$ 程 度と報告したが，この上限と今回明らかにされた環 境収容力 $\mathrm{K}$ の上限はほぼ一致していた。

変動強度 s の頻度分布 (図-3(b)) は左側に歪んでい る. 代表値は, 算術平均が $1.59[-]$, 最頻值が 0.75[-], 中央值が $1.39[-]$ であった. 最大值はSt.5(8月期)にお ける 5.85[-]で, この地点は感潮域に位置する。 この St.5に代表されるように, 変動強度sが高い上位 10 群 集のうち， 7 群集は感潮域に位置していた．全 70 群 集のうち感潮域が 17 群集であることを考慮すると, 上位 10 群集に占める感潮域の群集が割合が非常に高 いことがわかる.なお, ほとんどの感潮域の地点は護 岸はコンクリート, 河床は泥で覆われ ${ }^{333}$, 群集は主に ヤマトスピオ, ゴカイなどの汽水性の種で構成され る ${ }^{31}$. ところで, 変動強度 $\mathrm{s}$ の頻度分布には季節によ る特徵も見られた。この特徽は, 変動強度 $\mathrm{s}$ が $3.0[-]$ 以上の6群集が全て 8 月期の群集に限定されていたこ とである. また, 8 月期の群集の変動強度 $\mathrm{s}$ の平均値 は, 他の季節の平均値よりも有意に高かった $(\mathrm{t}$ 検定, $\mathrm{p}<0.01)$. 東京都では, 夏期に降水量が多くなるため, 増水による河床の擋乱や個体の移入・移出が他の季 節よりも活発になる.したがって,このような影響が 変動強度sへの主な影響因子となっていることが考え られる。

比増加速度 $\mathrm{r}$ の頻度分布 (図-3(c))は左側に歪んでい る. 代表値は, 算術平均が 1.17 [/ year], 最頻値が 0.75[/year], 中央值が 1.07[/year] であった。 また, 尖度は, 6.0-6.5[/year]階級に1つだけ離れた群集が 存在するため 3 つの頻度分布 $\left(\log _{10} \mathrm{~K}, \mathrm{~s}, \mathrm{r}\right)$ の中で最も 高かった.この $\mathrm{r}$ の值が突出して高い群集は感潮域に 位置するSt.5(8月期)で, その值は6.40[/year]だった.

この St.5(8 月期)の群集は変動強度 $\mathrm{s}$ の値も最も高 かった. しかし, 変動強度 $\mathrm{s}$ の場合と異なり, 比増加 速度 $\mathrm{r}$ が高い上位 10 群集のうち, 感潮域の群集数は 3 に止まったので, 感潮域の割合が上位 10 群集の中 
で特に高いというわけではなかった．ただし,この St.5(8月期)の群集は, 感潮域の全 17 群集の中で, 分 類数および多様性指数であるSimpson indexの12年間 の平均值が共に最高となっており, 比増加速度 $\mathrm{r}$ の突 出した高さとの関連性が考えられた.

\section{b) 実測値とモデル計算値(期待値)の比較}

パラメータ推定値は実際のバイオマスの動態をど の程度表現できているのだろうか. 本来ならば, 実測 值とモデル計算值の適合度からパラメー夕推定の妥 当性を確かめるのが望ましいが, 本研究で扱うよう な確率論的モデルの場合, この作業は難しい. しか し, モデルの解である確率密度関数(式(2))の期待値 と実測値の比較から, 実際の動態とパラメー夕推定 值に大きな隔たりがないか確認することはできる.

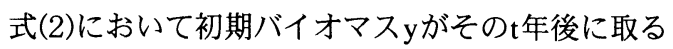
バイオマスの期待值 $\langle\mathrm{x}(\mathrm{t})\rangle$ は式(6)で与えられる22).

$$
\begin{aligned}
&\langle\mathrm{x}(\mathrm{t})\rangle=\lim _{\omega \rightarrow 0} \int_{\omega}^{\infty} \mathrm{xP}(\mathrm{x} \mid \mathrm{y}, \mathrm{t}, \mathrm{K}, \mathrm{r}, \mathrm{s}) \mathrm{dx} \\
&=\mathrm{K}\left(\frac{\mathrm{y}}{\mathrm{K}}\right)^{\exp (-\mathrm{rt})} \exp \left[\frac{\mathrm{s}^{2}\left(1-\mathrm{e}^{-2 \mathrm{rt}}\right)}{4 \mathrm{r}}\right]
\end{aligned}
$$

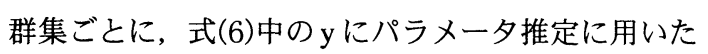
時系列データの 1 年目のバイオマス, パラメータ $(\mathrm{K}$, $\mathrm{s}, \mathrm{r})$ に各推定值をそれぞれ代入し, $\mathrm{t}=1,2 \cdots$ 一変化 させて期待値の経年変化を計算し, 実測值と比較し た.その結果の一部を図 -4に示す．ここには，バイ オマスが減少傾向にある群集(図-4(a)), ある一定レベ ルの周りを振動する群集(図-4(b)), 増加傾向にある 群集(図-4(c))のうち,それぞれの典型的な群集のみを 示した.

ここでは 3 例の結果のみ示したが, 全群集に関し て, これらのように期待値と実測値の経年変化の傾 向(収束レベル，増加(低下)率など)に類似性があり, 実際の動態特性とパラメー夕推定値 $(\mathrm{K}, \mathrm{s}, \mathrm{r})$ に大きな 隔たりがないことが確認された.しかし, 期待值は環 境変動によるバイオマスの変動の重心のみを表すの で, 実測值の変動が大きい群集の場合, 両者の適合度 を確認するのに十分であったかについては疑問が残 される.ただし，ここで推定されたパラメータの值が 考えられる中で最も実際の動態特性に近い値を示す と考え, 以降の生息環境や生物指標とパラメー夕の 相関を調べる解析はこれらの推定值を用いて行った.

\section{（2）生息環境とパラメータの相関関係}

表-3にパラメータと生息環境との相関関係を表す 単相関係数および $\mathrm{F}$ 検定の結果を示した. 参考のた め, 表には各環境変数の最大値, 最小值, および平均 值も示した. 3 つのパラメータの中で, 環境収容力 $\mathrm{K}$ (a) St.22(5 月期).

$\mathrm{K}=7466\left[\mathrm{mg} / \mathrm{m}^{2}\right], \mathrm{s}=0.45[-], \mathrm{r}=0.77[/$ year $]$

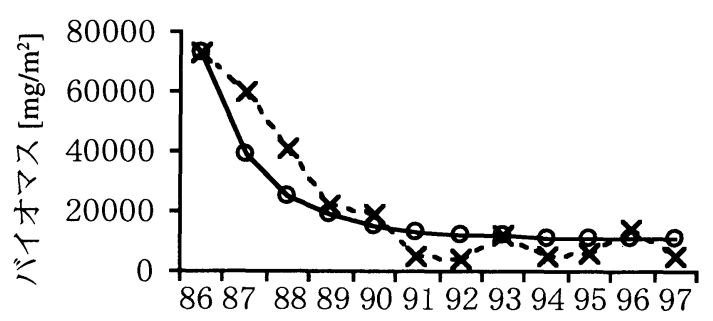

(b) St.34(11月期).

$\mathrm{K}=9769\left[\mathrm{mg} / \mathrm{m}^{2}\right], \mathrm{s}=0.91[-], \mathrm{r}=1.34[/ \mathrm{year}]$

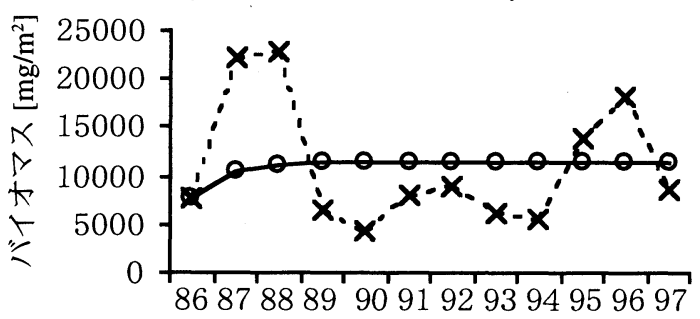

(c) St.28(11月期).

$\mathrm{K}=14655\left[\mathrm{mg} / \mathrm{m}^{2}\right], \mathrm{s}=0.90[-], \mathrm{r}=0.68[/$ year $]$

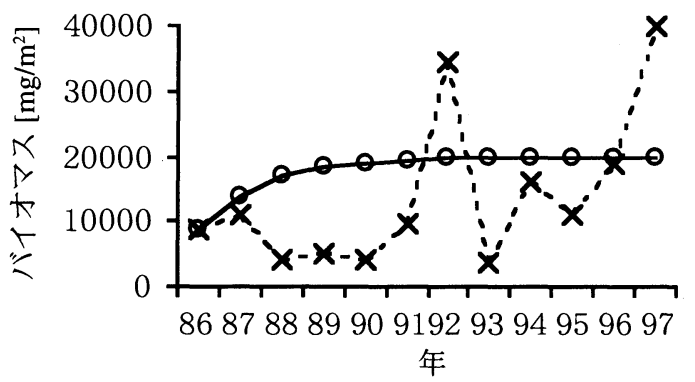

図-4 バイオマスの実測値と計算値(期待値)の比較.

---メ-- 実測値, 一一一計算値(期待値)を表す. (a) 減少,(b)一定レベルの周りを振動,(c)増加している群 集の典型例. 計算值(期待値)を式(6)加求める際, 初期バイオマス y には 1986 年の実測值を用いた.

が $7 つ$, 変動強度 $\mathrm{s}$ が 4 つの環境変数と有意な相関が あり, 河川環境との関連性が高かった. その一方で, 比増加速度 $\mathrm{r}$ は, 有意な相関が見られた環境変数は無 く, 河川環境が反映されにくいパラメータであるこ とが明らかになった。

水質項目の結果では, DO(溶存酸素濃度)が環境収 容力 $\mathrm{K}$ と正の有意な相関が認められた。溶存酸素濃 度が低い河川環境では貧酸素耐性種(イトミミズやユ スリカなど)を除いて生息が難しくなる ${ }^{17)}$.したがっ て, 貧酸素になるほど, 群集を構成する種の選択肢が 制限されてバイオマスの維持が難しくなり, 環境収 容力 $\mathrm{K}$ が低減するものと考えられる. 一方, DO と変 動強度 $\mathrm{s}$ の間では負の相関が見られた.これは, 一般 
表 -3 河川環境とパラメータの相関関係.単相関係数と F 検定の結果を示している. ${ }^{*}$ は $1 \%,{ }^{* *}$ は $5 \%$ の有意水準で棄却 されたことをそれぞれ表す.

\begin{tabular}{|c|c|c|c|c|c|c|c|c|}
\hline & 環境変数 & 単位 & 平均値 & 最小值-最大値 & $\begin{array}{c}\text { 環境収容力 } \\
\mathrm{K}\left[\mathrm{mg} / \mathrm{m}^{2}\right]\end{array}$ & $\begin{array}{c}\text { 変動強度 } \\
\mathrm{s}[-]\end{array}$ & $\begin{array}{c}\text { 比増加速度 } \\
\text { r/year] }\end{array}$ & $\begin{array}{c}\text { バイオマス } \\
{\left[\mathrm{mg} / \mathrm{m}^{2}\right]} \\
\end{array}$ \\
\hline 水質 & $\overline{\mathrm{DO}}$ & $\mathrm{mg} / \ell$ & $\overline{8.0}$ & $3.6-10.6$ & $0.27^{*}$ & $-0.32^{* *}$ & -0.02 & $0.35^{* *}$ \\
\hline \multirow[t]{7}{*}{ 項目 } & COD & $\mathrm{mg} / \mathrm{l}$ & 6.4 & $1.2-18.1$ & -0.21 & 0.17 & -0.01 & 0.03 \\
\hline & BOD & $\mathrm{mg} / \mathrm{l}$ & 5.0 & $0.7-19.7$ & -0.03 & 0.03 & -0.01 & -0.18 \\
\hline & SS & $\mathrm{mg} / \mathrm{l}$ & 13.5 & $1.9-33.7$ & $-0.45^{* *}$ & 0.15 & 0.02 & 0.07 \\
\hline & 電気伝導度 & $\mu \mathrm{S} / \mathrm{cm}$ & 1622 & $91-19767$ & $-0.26^{*}$ & $0.51^{* *}$ & 0.22 & -0.21 \\
\hline & $\mathrm{pH}$ & - & 7.5 & $7.0-8.2$ & $-0.24^{*}$ & -0.11 & 0.10 & -0.11 \\
\hline & 全りん & $\mathrm{mg} / \ell$ & 0.41 & $0.01-1.14$ & -0.07 & 0.22 & 0.02 & 0.11 \\
\hline & 全窒素 & $\mathrm{mg} / \mathrm{l}$ & 6.6 & $0.7-21.8$ & -0.05 & 0.10 & -0.11 & 0.12 \\
\hline 物理 & 標高 & $\mathrm{m}$ & 48.1 & $-1.0-187.0$ & $0.44^{* *}$ & $-0.25^{*}$ & -0.09 & -0.10 \\
\hline \multirow[t]{3}{*}{ 項目 } & 低水路幅 & $\mathrm{m}$ & 63.6 & $4.0-425.0$ & $-0.31^{* *}$ & 0.22 & -0.04 & 0.22 \\
\hline & 流量 & $\mathrm{m}^{3} / \mathrm{sec}$ & 17.2 & $0.2-131.3$ & $-0.72^{* *}$ & -0.18 & -0.11 & $-0.32^{* *}$ \\
\hline & 集水面積 & $\mathrm{km}^{2}$ & 167.8 & $5-960.0$ & 0.04 & $0.24^{*}$ & 0.14 & 0.15 \\
\hline
\end{tabular}

的に貧酸素状態が発生するような環境ではDO 自体 が年変動しやすいこと,また, 貧酸素耐性種のバイオ マスの安定性がその他の種よりも低いことなどが影 響した結果として推測される.

環境収容力 $\mathrm{K}$ と負の相関があった SS(浮遊物質量) が表す水中の浮遊土砂やシルトなどは, 河床の石の 表面や隙間に沈殿する。底生動物は河床に生息して いるため, 種を問わずダメージが与えられる17).この 影響がここでの相関関係に表れたものと考えられる.

ところで, 対象とした 70 群集の中には, 下流域に 位置して潮汐や流量の影響で海水が進入する地点も 含まれる. 海水が混合するほど電気伝導度は上昇し, $\mathrm{pH}$ は上昇するので, これら 2 つ環境変数を海水の 混合度合いを表す指標として考える. 海水が進入す る生息域には, 塩分濃度に耐性を示す底生動物(ヤマ トシジミやゴカイなど)が生息し, 淡水域とは大きく 異なる生態系が構築される ${ }^{34)}$. 電気伝導度と $\mathrm{pH}$ に関 する相関関係から, 海水が流入する生息域ほど環境 収容力 $\mathrm{K}$ が低く, 変動強度 $\mathrm{s}$ が高くなる傾向がわかる. このうち, 環境収容力 $\mathrm{K}$ の相関の原因として, 海水の 進入により塩分耐性を持つ種以外の生息が困難にな り，環境が維持できるバイオマスの容量が低下する ことが考えられる. また, 変動強度 $\mathrm{s}$ の相関の原因と して, 海水が進入する下流域は河床堆積物の粒径が 非常に小さく, 流量変動に伴う河床が擋乱されやす
いことが考えられる.なお, 河川への塩水の進入はシ ルトなどの懸濁成分を沈降させる効果がある ${ }^{34) .}$

物理項目では, 標高, 低水路幅, および流量の 3 変 数が環境収容力 $\mathrm{K}$ と有意な相関があった. 標高が低 くなるにつれて河川形態は上流から中流そして下流 へと変化し, 低水路幅および流量はその地点におけ る河川の規模を表す.一般的に, 河川の規模は下流に 進むに伴って大きくなるため,これら 3 つの環境変数 は深く関わり合っている.これら3変数と環境収容力 $\mathrm{K}$ の相関の符号から, 下流に進み, 河川の規模が大き くなるほど環境収容力 $\mathrm{K}$ は小さくなる傾向が明らか になった.これは, 上流から下流にかけての環境の変 化( 流速の低下, 底質の細粒化, 透明度の低下等)が群 集のバイオマスの維持容量を低化させていることを 示している.

変動強度 $\mathrm{s}$ は標高および集水面積と有意な相関が あった.このうち集水面積との相関は正だった. 集水 面積が大きい地点ほど, 降水時に流量および流速が 増加し, 河床材料が変動しやすい. したがって,ここ での正の相関は, 降水による環境(特に河床)変動の影 響が反映された結果として理解される.

また, バイオマスは流量と低水路幅以外の全ての 環境変数と有意な相関はなかった. したがって, 本研 究で評価したバイオマスの動態特性を表すパラメー 夕のうち, 環境収容力 $\mathrm{K}$ と変動強度 $\mathrm{s}$ はバイオマスそ

表 -4 既存の生物指標とパラメータの相関関係. 単相関係数と F 検定の結果を示している.*は $1 \%,{ }^{* *}$ は $5 \%$ の 有意水準で棄却されたことをそれぞれ表す.

\begin{tabular}{cccc|c|c|c}
\hline 生物指標 & 単位 & 平均值 & 最小值 - 最大值 & $\begin{array}{c}\text { 環境収容力 } \\
\mathrm{K}\left[\mathrm{mg} / \mathrm{m}^{2}\right]\end{array}$ & $\begin{array}{c}\text { 変動強度 } \\
\mathrm{s}[-]\end{array}$ & $\begin{array}{c}\text { 比増加速度 } \\
\mathrm{r}[/ \mathrm{year}]\end{array}$ \\
\hline バイオマス & $\mathrm{mg} / \mathrm{m}^{2}$ & 26371.9 & $131.9-207583$ & $\mathbf{0 . 4 3} \mathbf{3}^{* *}$ & 0.22 & $-\mathbf{0 . 2 5 ^ { * }}$ \\
総個体群密度 & $\mathrm{ind} / \mathrm{m}^{2}$ & 4558.4 & $56.6-67734$ & $\mathbf{0 . 2 7 ^ { * }}$ & 0.21 & 0.02 \\
多様性指数 & - & 0.58 & $0.11-0.90$ & $\mathbf{0 . 5 2} \mathbf{2}^{* *}$ & -0.14 & 0.09 \\
分類数 & $\mathrm{taxa}$ & 14.7 & $1.1-41.0$ & $\mathbf{0 . 5 8}$ & -0.19 & 0.04 \\
\hline
\end{tabular}


のものでは評価しにくい河川環境の状態が良く反映 されていた.

\section{（3）パラメータと既存の生物指標の相関関係}

表 -4 にパラメータと既存の生物指標の相関分析の 結果を示した. 一般に, バイオマス, 総個体群密度, 多様性指数, 種数が高い群集ほど生息状態が健全と される. 環境収容力 $\mathrm{K}$ はすべての生物指標と有意な 正の相関があった. よって, 環境収容力 $\mathrm{K}$ は群集の健 全さと共に高まる性質を持つパラメータと言える. また,このことから逆に, 前述した環境収容力が高い 河川環境の特徵(高いDO, 低いSS, 上流, 小規模)を 有する群集ほど生息状態が健全になると考えられる.

また, 比増加速度 $\mathrm{r}$ はバイオマスと負の相関が見ら れた.この相関は, 平均的にバイオマスが高い状態で 経年推移している群集の方が増加速度が低くなる傾 向を説明している.このことから,バイオマスが高い 群集に対して一時的なインパクト(土木工事等)を与え てバイオマスを低下させた場合, より長い回復時間 を要することが推測される.したがって, バイオマス が高い群集に対して人為的にインパクトを与える際 には, その回復速度の観点からもより慎重になる必 要があると言える.

\section{4. 結論}

本研究では底生動物のバイオマスの経年変化を表 すモデルとして, 決定論的に密度依存性を表現する Gompertz モデルに環境変動を表す確率変動成分を組 み合わせたモデルを選択した. そして，ケーススタ ディーとして東京都内に分布する700底生動物群集 を対象にしてモデルパラメータ( 環境収容力 $\mathrm{K}$, 比増 加速度定数 $\mathrm{r}$, 変動強度 $\mathrm{s}$ )による動態特性の把握を行 い, パラメータと河川環境および既存の生物指標の 関係を明らかにした。本研究の主な結論を以下にま とめる.

・最尤推定法により上記 70 群集のパラメータ推定を 行い, 環境収容力 $\mathrm{K} は 54-79479\left[\mathrm{mg} / \mathrm{m}^{2}\right]$, 変動強度 $\mathrm{s}$ は0.13-5.85[-], 比増加速度 $\mathrm{r}$ は 0.02-6.40[/year]の 範囲でそれぞれ推定された.

・東京都では, バイオマスの維持に適した河川環境で あっても，環境収容力 $\mathrm{K}$ には約 $80\left[\mathrm{~g} / \mathrm{m}^{2}\right]$ 程度の上限 值が存在した。

• 8 月期の群集は他の季節の群集よりも経年変化の変 動強度 $\mathrm{s}$ が比較的高かった.

・生息環境の溶存酸素濃度(DO)が低い群集ほど環境
収容力 $\mathrm{K}$ が低く, 変動強度 $\mathrm{s}$ が高い傾向があつた.ま た, 浮遊物質量(SS)が高い生息環境ほど環境収容力 $\mathrm{K}$ が低くなっていた.

・海水が流入する地点の群集ほど, 環境収容力 $\mathrm{K}$ の値 が低く, 変動強度 $\mathrm{s}$ の值が高くなる傾向が見られた. ・下流側に進み, 河川の規模が大きくなるほど環境収 容力 $\mathrm{K}$ は小さくなる傾向があった.

・バイオマスの動態特性を表すパラメータのうち, 環 境収容力 $\mathrm{K}$ 変動強度 $\mathrm{s}$ はバイオマスそのものでは評 価しにくい河川環境の状態が良く反映されていた.

・環境収容力 $\mathrm{K}$ は群集の健全さ(バイオマス, 総個体 群密度, 多様性指数, 分類数) と共に高まる.

謝辞： 本稿は, 東京都が実施した水生生物および水 環境調査で得られたデータをもとに, 独自の解析を 行った結果をまとめたものである. 本研究の遂行に あたり東京都環境局の風間真理氏から多大なご助言 や貴重な文献を頂いた. また, 本研究の一部には平成 14 年度文部科学省科学技術研究費補助金(特別研究員 奖励費)を使用した.ここに記して感謝の意を表する.

\section{付録 1 最⿺尢丶推定法による時系列データとパラ メータの関係式の導出}

$\mathrm{i}=1,2 \cdot ・ n-1$ に関して, $\mathrm{i}$ 年目のバイオマス $\mathrm{x}_{\mathrm{i}}$ が その $\tau$ 年後に $\mathrm{x}_{\mathrm{i}+\tau}$ に変化する確率 $\mathrm{P}\left(\mathrm{x}_{\mathrm{i}+\tau} \mid \mathrm{x}_{\mathrm{i}}, \tau, \mathrm{K}, \mathrm{r}, \mathrm{s}\right)$ を全 て乗じた尤度関数 L は

$$
\begin{array}{r}
\mathrm{L}=\mathrm{P}\left(\mathrm{x}_{1+\tau} \mid \mathrm{x}_{1}, \tau, \mathrm{K}, \mathrm{r}, \mathrm{s}\right) \times \mathrm{P}\left(\mathrm{x}_{2+\tau} \mid \mathrm{x}_{2}, \tau, \mathrm{K}, \mathrm{r}, \mathrm{s}\right) \times \\
\cdots \times \mathrm{P}\left(\mathrm{x}_{\mathrm{n}} \mid \mathrm{x}_{\mathrm{n}-\tau}, \tau, \mathrm{K}, \mathrm{r}, \mathrm{s}\right)
\end{array}
$$

となる. 本文中の式(2)を考慮すると

$$
L=\frac{1}{x_{1+\tau} \cdots x_{n}}\left(\frac{A}{\pi}\right)^{\frac{n-\tau}{2}} \exp \left[-A \sum_{i=1}^{n-\tau}\left\{U\left(x_{i}\right)\right\}^{2}\right]
$$

となる.ただし，

$$
\begin{aligned}
& U\left(x_{i}\right)=\ln \frac{x_{i+\tau}}{K}\left(\frac{K}{x_{i}}\right)^{\exp (-r \tau)} \\
& A=r / s^{2}\left(1-e^{-2 r \tau}\right)
\end{aligned}
$$

である.したがって，対数尤度関数は

$$
\begin{aligned}
\ln L & =-\sum_{i=1+\tau}^{n} \ln x_{i}+\frac{n-\tau}{2} \ln \left(\frac{r}{\pi s^{2}\left(1-e^{-2 r \tau}\right)}\right) \\
& -\frac{r}{s^{2}\left(1-e^{-2 r \tau}\right)} \sum_{i=1}^{n-\tau}\left\{\ln \frac{x_{i+\tau}}{K}\left(\frac{K}{x_{i}}\right)^{\exp (-r \tau)}\right\}^{2}
\end{aligned}
$$


となる. 推定值を求めるには, この対数尤度関数を最 大にすれば良いので, 式(7)の両辺を各パラメータに 関して微分して 0 となる値を求める.

Kで微分した場合，

$$
\frac{\partial \ln L}{\partial K}=-A \sum_{i=1}^{n-\tau} 2\left\{\ln \frac{x_{i+\tau}}{K}\left(\frac{K}{x_{i}}\right)^{\exp (-r \tau)}\right\}\left\{\frac{1}{K}-\frac{e^{-r \tau}}{K}\right\}=0
$$

となり $, 1 / \mathrm{K}-\mathrm{e}^{-\tau} \tau / \mathrm{K} \neq 0, \mathrm{~A} \neq 0$ を考慮すると

$$
\sum_{i=1}^{n-\tau} \ln \left\{\frac{x_{i+\tau}}{K}\left(\frac{K}{x_{i}}\right)^{\exp (-r \tau)}\right\}=0
$$

となる. この式を更に変形すると本文中の式(4)が得 られる.

次に, 式(7)を $\mathrm{s}$ で微分した場合,

$$
\begin{aligned}
& \frac{\partial \ln L}{\partial s}=-\frac{n-\tau}{s} \\
& +\frac{2 r}{s^{3}\left(1-e^{-2 r \tau}\right)} \sum_{i=1}^{n-\tau}\left\{\ln \frac{x_{i+\tau}}{K}\left(\frac{K}{x_{i}}\right)^{\exp (-r \tau)}\right\}^{2}=0
\end{aligned}
$$

となり, まとめると本文中の式(5)が得られる.

最後に, 式(6)を $\mathrm{r}$ で微分した場合,

$$
\begin{aligned}
& \frac{\partial \ln L}{\partial \mathrm{r}}=\frac{\mathrm{n}-\tau}{2} \frac{1-\mathrm{e}^{-2 \mathrm{r} \tau}(1+2 \mathrm{r})}{\mathrm{r}\left(1-\mathrm{e}^{-2 \mathrm{r} \tau}\right)} \\
& -\frac{1-\mathrm{e}^{-2 \mathrm{r} \tau}(1+2 \mathrm{r})}{\mathrm{s}^{2}\left(1-\mathrm{e}^{-2 \mathrm{r} \tau}\right)^{2}} \sum_{\mathrm{i}=1}^{\mathrm{n}-\tau}\left[\ln \left\{\frac{\mathrm{x}_{\mathrm{i}+\tau}}{\mathrm{K}}\left(\frac{\mathrm{K}}{\mathrm{x}_{\mathrm{i}}}\right)^{\exp (-\mathrm{r} \tau)}\right\}\right]^{2} \\
& +\frac{2 \mathrm{r}}{\mathrm{s}^{2}\left(1-\mathrm{e}^{-2 \tau \tau}\right)} \sum_{\mathrm{i}=1}^{\mathrm{n}-\tau} \ln \left(\frac{\mathrm{x}_{\mathrm{i}}}{\mathrm{K}}\right) \ln \left\{\frac{\mathrm{x}_{\mathrm{i}+\tau}}{\mathrm{K}}\left(\frac{\mathrm{K}}{\mathrm{x}_{\mathrm{i}}}\right)^{\exp (-\mathrm{r \tau})}\right\}=0
\end{aligned}
$$

となる. 本文の式(5)を代入すると

$$
\begin{aligned}
& \frac{\mathrm{n}-\tau}{2} \frac{1-\mathrm{e}^{-2 r \tau}(1+2 \mathrm{r})}{\mathrm{r}\left(1-\mathrm{e}^{-2 \mathrm{r} \tau}\right)} \\
& -\frac{1-\mathrm{e}^{-2 r \tau}(1+2 \mathrm{r})}{\mathrm{s}^{2}\left(1-\mathrm{e}^{-2 r \tau}\right)^{2}} \frac{\mathrm{s}^{2}(\mathrm{n}-1)\left(1-\mathrm{e}^{-2 r \tau}\right)}{2 \mathrm{r}} \\
& +\frac{2 \mathrm{r}}{\mathrm{s}^{2}\left(1-\mathrm{e}^{-2 r \tau}\right)} \sum_{\mathrm{i}=1}^{\mathrm{n}-\tau} \ln \left(\frac{\mathrm{x}_{\mathrm{i}}}{\mathrm{K}}\right) \ln \left\{\frac{\mathrm{x}_{\mathrm{i}+\tau}}{\mathrm{K}}\left(\frac{\mathrm{K}}{\mathrm{x}_{\mathrm{i}}}\right)^{\exp (-\mathrm{r \tau})}\right\}=0
\end{aligned}
$$

となる. 左辺第 1 項目と 2 項目は互いに打ち消し合う ので,

$$
\sum_{i=1}^{n-1} \ln \left(\frac{x_{i}}{K}\right) \ln \left\{\frac{x_{i+1}}{K}\left(\frac{K}{x_{i}}\right)^{\exp (-r)}\right\}=0
$$

とまとめられる.この式は

$$
\begin{aligned}
& (n-\tau)\left(1-e^{-r \tau}\right)(\ln K)^{2}-\ln K \sum_{i=1}^{n-\tau}\left[\ln \left\{\frac{x_{i+\tau}}{x_{i} \exp (-r \tau)}\right\}\right] \\
& -\left(1-e^{-r \tau}\right) \ln K \sum_{i=1}^{n-\tau} \ln x_{i}+\sum_{i=1}^{n-\tau}\left[\ln x_{i} \ln \left\{\frac{x_{i+\tau}}{x_{i}{ }^{\exp (-r \tau)}}\right\}\right]=0
\end{aligned}
$$

に変形される. 式(8)の $\ln K$ に本文中の式(4)の右辺を 代入する. すると, 式(8)の左辺第 1 項と第 2 項が互 いに打ち消しあい,

$$
\begin{aligned}
-\frac{1}{(n-\tau)} \sum_{i=1}^{n-\tau}\left[\ln \left\{\frac{x_{i+\tau}}{x_{i} \exp (-\tau \tau)}\right\}\right] \sum_{i=1}^{n-\tau} \ln x_{i} \\
+\sum_{i=1}^{n-\tau}\left[\operatorname { l n } x _ { i } \operatorname { l n } \left\{\frac{x_{i+\tau}}{\left.\left.x_{i}{ }^{\exp (-r \tau)}\right\}\right]=0}\right.\right.
\end{aligned}
$$

となる.この式を $\mathrm{e}^{-\tau} \tau$ に関してまとめると本文中の式 (3)が得られる.

付録 $20\left[\mathrm{mg} / \mathrm{m}^{2}\right]$ のデータに対する近似值の代 用がパラメー夕推定に与える影響

ここでは，適用限界(1)に当てはまった 10 群集のう ち, St.2(8月期)の 1 群集を例に考える.なお, St.2(8 月期)は, 12 年間のうちバイオマスが $0\left[\mathrm{mg} / \mathrm{m}^{2}\right]$ になっ たは 1988 年のみである.ここで, $0\left[\mathrm{mg} / \mathrm{m}^{2}\right]$ の 1988 年のバイオマスに 12 年間の算術平均を $10^{-1}$ 倍, $10^{-2}$ 倍・・・10-9 倍した值を代用してパラメータ $(\mathrm{K}, \mathrm{s}, \mathrm{r})$ を推定した. その結果, 算術平均に乗じた倍率を小さ くするに伴い, $\mathrm{K}$ と $\mathrm{r}$ の推定值は増加し, $\mathrm{s}$ の推定値 は低下した(図-5).したがって, $0\left[\mathrm{mg} / \mathrm{m}^{2}\right]$ のデータ に代用する值の大きさが推定結果に大きく影響する ことが明らかになった.この傾向はSt.2(8月期)に限 らず, 10 群集すべてについて見られた. 以上より, 時 系列に $0\left[\mathrm{mg} / \mathrm{m}^{2}\right]$ にパラメータを推定するために他の 值を代用すると, 代用した値の大きさが推定値に大 きく影響するため, 適切ではないことがわかった.

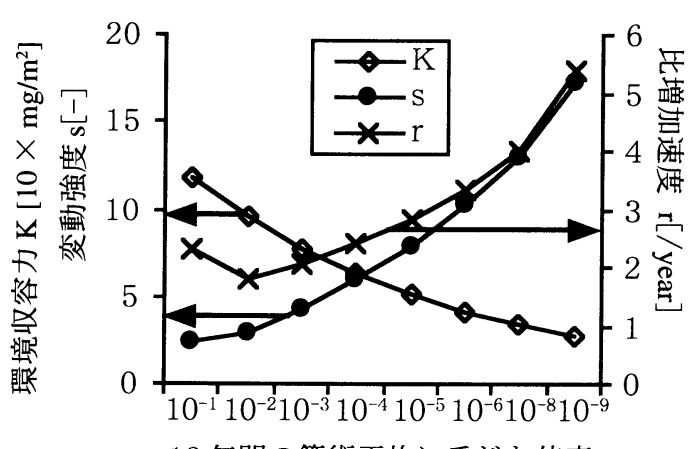

12 年間の算術平均に乗じた倍率

図-5 St.2(8月期)において, $0\left[\mathrm{mg} / \mathrm{m}^{2}\right]$ の年に, 12 年間の 算術平均を $10^{-1}$ 倍, $10^{-2}$ 倍・・・1 $10^{-9}$ 倍した値をそ れぞれ代用した時のパラメー夕推定値 $(\mathrm{K}, \mathrm{s}, \mathrm{r})$ の倍率 に伴う変化 


\section{参考文献}

1）大町利勝，国土交通省河川局 : 注釈河川法，国際建設技 術協会, pp.105, 1999.

2）島谷幸宏 : 近年の河川環境の変化と河川整備, 河川環境 の保全と復元, 鹿島出版会, pp.2-10, 2000 .

3）建設省河川局河川環境課 : 河川水辺の国勢調査年鑑（平 成 11 年度・河川版)，山海堂, pp. 69, 2001.

4）仙台市下水道局 : 広瀬川水族棲息環境調查報告書, pp. $1-44,1989$.

5) 谷田一三: 水生昆虫で河川環境を見る, 第31回日本水環 境学会セミナ一講演資料集, pp. 50-71, 1977.

6) Hauer, F. R. and Lamberti G. A. : Methods in Stream Ecology, Academic Press, pp. 339-369, 1996.

7) Barbour, M. T., Gerristen, J. T., Snyder, B.D. and Stribring, J.B. : Rapid Bioassessment Protocols For Use in Streams and Wadeable Rivers: Periphyton, Benthic Macroinvertebrates and Fish, EPA, 2001.

8) Yoshimura, C., Kumagai, Y., Fukushi, K. and Omura, T.: Ecological Co-inhabitance Index (ECI) as a Management Tool for the Ecosystem Preservation in River, Water Science and tech nology, Vol. 43-44, pp. 161-170, 2001.

9)御勢久右衛門: 大和吉野川における瀬の底生動物群集の 遷移，日本生態学会誌，Vol. 18, No.4, pp. 147-157, 1968.

10)小松典: 渓流の瀬における極相の底生動物群集の季節変 動および年次変動, 日本生態学会誌, Vol. 25, No.3, pp. 43-49, 1975

11)Niemi, G. J., Devore, P., Detenbeck, N., Taylor, D., Lima, A. and Pastor, J.: Overview of Case Studies on Recovery of Aquatic System from Disturbance, Environmental Management, Vol. 14, No.5, pp.571-587, 1990.

12) Yount, J. D. and Niemi G. J.: Recovery of lotic communities and ecosystems from disturbance - a narrative review of case studies. Environmental Management, Vol. 14, No.5, pp.547-569, 1999.

13)䉷佐庸: 数理生物学入門 - 生物社会のダイナミックス を探る, 共立出版, pp.571-587, 1998.

14)Hakoyama, H., Iwasa, Y. and Nakanishi, J.: Comparing Risk Factors for Population Extinction, J. theor. Biology.,Vol. 204, pp.327-336, 2000.

15)Hakoyama, H. and Iwasa, Y., : Extinction Risk of a Densitydependent Population Estimated from a Time Series of Population Size, J. theor. Biology., Vol. 204, pp.337-359, 2000.
16)楠田哲也, 䉷佐庸: 生態系とシミュレーション, pp.3143, 2002.

17)水野信彦, 御勢久右衛門: 河川の生態学, 築地書館, pp.32-99, 2000.

18）新名史典 : 河川昆虫群集の食物網 多様性と動態, 海 洋と生物, Vol. 107, No. 6, pp. 434-440, 1996.

19) Allan, J. D. : Stream Ecology, Kluwer Academic Publishers, pp.131-237, 2000.

20) Scarsbrook, M. R. : Persistence and stability of lotic invertebrate communities in New Zealand, Freshwater Biology, Vol. 47, pp.417-431, 2002.

21) Taylor, C. M. and Warren, M. L. J. : Dynamics in species composition of stream fish assemblages: environmental variability and nested subsets, Ecology, Vol. 82, No.8, pp.23202330, 2001.

22)Goel N. S., Richter-Dyn N.（寺元英訳）:生物学における 確率過程の理論 , 産業図書 , pp.140-154, 1978 .

23)Pielou E. C. (南雲甚一, 合田周平, 藤村貞夫訳): 数理生 態学, 産業図書, pp. 23-27, 1974.

24)Waters. T. F. : Secoundary production in inland waters, $A d$ vanced in Ecological Reserch, 10, pp.91-164, 1977

25)Kleinbaum, D. G., Kupper, L. L. and Muller, K. E. : Applied Regression Analysis and Other Multivariable Method, Duxbury Press, pp.483-496, 1988.

26)東京都環境保全局水質保全部，水生生物調査結果報告 書, 1988-1999.

27) Malmqvist, B.: Aquatic invertebrates in riverine landscapes, Freshwater Biology, Vol.47, pp.679-694, 2002.

28) Bravard, J., Amorous, C. and Pautou, G.: Impact of civil engineering works on the successions of communities in fluvial system, OIKOS, Vol.47, pp. 92-111, 1986.

29）玉井信行, 水野信彦, 中村俊六 : 河川生態環境工学, 東京大学出版会, pp. 312, 1993.

30）東京都環境保全局：公共用水域及び地下水の水質測定 結果, 1987-1998.

31) Simpson, E. H. : Measurement of diversity, Nature, Vol. 163, No.4148, pp.688, 1949.

32）津田松苗 : 水生昆虫学, 北隆館, pp. 238-241, 1983.

33）東京都環境保全局水質保全部 : 東京の川の生きものと 環境 - 河川水生生物総合解析超過報告書（その 2), pp. $7,1998$.

34) 有田正光, 池田裕一, 中井正則, 中村由行, 道奥康治, 村上和男 : 河口部の環境, 水圏の環境, 東京電気大学出 版会, pp. 360-365, 1998 .

(2002.7. 18 受付) 


\section{EVALUATION FOR DYNAMICS OF BENTHIC FAUNAL COMMUNITIES IN RIVERS WITH ECOLOGICAL PARAMETERS}

\section{Kozo WATANABE, Chihiro YOSHIMURA, Takashi OGAWARA and Tatsuo OMURA}

In order to evaluate annual dynamics of biomass for benthic faunal community, the ecological parameters (Carrying Capacity, K; Specific Growth Rate, r; Oscillation Intensity, s) of benthic faunal communities at the 70 river sites in the Tokyo metropolitan area were estimated. As a result, the value of $\mathrm{K}, \mathrm{r}, \mathrm{s}$ were in the range of $54-79479\left[\mathrm{mg} / \mathrm{m}^{2}\right], 0.02-6.40$ [/year], and 0.13-5.85 [-], respectively. The statistical analysis revealed the two parameters, $\mathrm{K}$ and s, were related to physical and chemical factors in their habitats (e.g., dissolved oxygen and suspended solid concentrations, and discharge). 